\title{
LEXICON
}

\section{PROMISE CATEGORIES IN SOME AMERICAN DRAMA MOVIES}

\author{
Aida Minati Rohmah
}

\begin{abstract}
INTISARI
Skripsi ini meneliti tentang janji dalam lima film drama Amerika. Data terdiri dari janji yang dikumpulkan dari subtitel film Dear John, For Love of the Game, Going the Distance, Like Crazy, and The Notebook. Secara khusus, penelitian ini bertujuan untuk mengidentifikasi dan mengkategorikan janji, serta untuk menemukan tipe dominan yang muncul dalam film tersebut. Pengklasifikasian janji berdasarkan pada empat felicity conditions yang dirumuskan Searle: proportional condition, preparatory condition, sincerity condition, dan essential condition. Hasil penelitian menunjukkan bahwa semua janji telah memenuhi empat felicity conditions dan frekuensi penggunaan janji tertinggi muncul dalam film Like Crazy (24,66\%). Hasil dari penelitian juga menunjukkan bahwa 65 janji $(89,04 \%)$ dikategorikan sebagai implicit performatives dan tipe ini muncul sebagai tipe janji yang dominan pada data. Tingginya angka penggunaan implicit performatives menandakan bahwa penutur ingin menunjukkan niat mereka dalam melakukan sesuatu dengan cara yang sederhana.
\end{abstract}

Kata kunci: tindak tutur, janji, felicity conditions, explicitness, konteks

\begin{abstract}
This research attempts to investigate the promises in five American drama movies. The data comprise 73 promises collected from the subtitles of the movies Dear John, For Love of the Game, Going the Distance, Like Crazy, and The Notebook. Specifically, it aims to identify and categorize the promises, and to find out the more dominant type appears in those movies. The classification of the promises was according to Searle's four felicity conditions: proportional condition, preparatory condition, sincerity condition, and essential condition. Based on the classification, it can be seen that all of the promises have fulfilled the four felicity conditions and the highest frequency of promises occurred in the movie Like Crazy $(24.66 \%)$. The result also shows that 65 promises $(89.04 \%)$ are categorized as implicit performatives and it appears as the more dominant type of promises in the data. The high number of implicit performatives indicates that the speakers might want to show their intention to do something in a casual way.
\end{abstract}

Keywords: speech act, promises, felicity conditions, explicitness, context 


\section{INTRODUCTION}

A speech act is an action performed by a speaker with an utterance. If a speaker utters, "I'll be there at six," he is not just speaking. He is actually also performing the speech act of 'promising' (Yule, The Study of Language 133). According to Searle, promises have been the object of attention, at least in the formal sense of specifying preconditions and contexts for their occurrence and success (qtd. in Hickey 69). The term commitment basically means the binding of someone to a certain action. This also implies a hearer, as no commitments are made as monologues under normal circumstances. Thus, there is a second partner to the commitment. The hearer's role is essential since a commitment is made to a person. If the hearer does not hear or accept the commitment, it will be invalid (Hickey 70).

It is interesting to investigate promises since people utter promises in different ways, which might bring with them a consequence of being misunderstood. People often wonder whether an utterance is a promise or not when it does not contain the verb 'promise'. Thus, it is important as well as interesting to investigate the conditions that should be met in making promises.

This research attempts to investigate the promises that appear in American drama movies Dear John, For Love of the Game, Going the Distance, Like Crazy, and The Notebook. Drama movies, in this case the subtitles, are chosen as the data source since conversations likely appear more frequently in this movie genre. All of the movies tell about long distance relationships between young lovers. They have similar background stories where two people fall in love but they have to face the challenges of being apart at the same time. The characters believe that their love will survive despite the problems they have to face, so they try to assure each other of their love by making promises. The main goal of this research is to identify and categorize the speech act of promising in those five movies.

This research attempts to identify the promises in five American drama movies according to Searle's felicity conditions and categorize the promises according to explicitness proposed by Austin to see the more dominant type that appears in the movies.

The data were obtained from the subtitles of five American drama movies entitled Dear John, For Love of the Game, Going the Distance, Like Crazy, and The Notebook. The data of this research are all promises found in those movies. Observation method was used in the data collection. The data were classified based on the four felicity conditions: proportional condition, preparatory condition, sincerity condition, and essential condition. Based on the classification, the data were categorized according to their explicitness. There are two types of promises: implicit performatives and explicit performatives.

\section{SPEECH ACTS}

Pragmatics is the study of meaning as communicated by a speaker and hearer. This study needs interpretation to understand the context of utterances (Yule, Pragmatics 3). In expressing something, the speaker does not only produce utterances containing grammatical structures, but he also performs an act, such as promising, requesting, apologizing, etc. It is what Yule calls speech acts (Yule, Pragmatics 47). Another expert in pragmatics, Austin, suggests the three types of acts. They are locutionary act, illocutionary act, and perlocutionary act (102-103). Since this research in general also deals with those three acts, some explanation about the acts are given below.

Locutionary act: An act of uttering the literal meaning of what the speaker says.

[1a] (Taken from Dear John) 
Steve (speaker): "I don't want any trouble here."

John (hearer): "You're not get any. I promise."

The statement above performs an act from the speaker that he does not want any trouble in that place.

Illocutionary act: An act where the speaker performs some actions with his utterance, such as promising, offering, warning, etc.

[1b] (Taken from Dear John)

$$
\begin{aligned}
& \text { Steve (speaker) : "I don't want } \\
& \text { any trouble here." } \\
& \text { John (hearer) "You're not } \\
& \text { get any. I promise." }
\end{aligned}
$$

The example in [1b] implies that the speaker is not only stating something, but he is also warning the hearer not to make any trouble. He might also refuse the hearer for entering that place.

Perlocutionary act: The result of the utterance that has been produced. This causes a consequence for someone to do something.

[1c] (Taken from Dear John)

$$
\begin{aligned}
& \text { Steve (speaker) : "I don't want } \\
& \text { any trouble here." : "You're not } \\
& \text { John (hearer) } \\
& \text { get any. I promise." }
\end{aligned}
$$

The utterance that has been stated by the speaker in [1c] shows the way the speaker stops the hearer for entering that place.

Another suggestion related to speech acts also comes from Searle (qtd. in Mey 119-120). He divides speech acts into five categories. They are representatives, directives, commissives, expressives, and declarations. Below is the explanation of those categories. Some examples of the categories will be included in the following explanation (Yule, Pragmatics 53-54).

Representatives: Those utterances that show the speaker's expression in informing something. For example: asserting, claiming, stating, etc.

[2] The earth is flat.

[3] It was a warm sunny day.
Directives: Utterances that show the speaker's intention to get the hearer to do something. For example: requesting, commanding, suggesting, etc.

[4] Gimme a cup of coffee. Make it black.

[5] Could you lend me a pen, please?

Commissives: Utterances that show the speaker's commitment and intention to do a future action. For example: promising, warning, refusing etc.

[6] I'll be back.

[7] I'm going to get it right next time.

Expressives: Utterances that show the speaker's psychological expression. For example: apologizing, thanking, congratulating, etc.
[8] I'm really sorry!
[9] Congratulations!

Declarations: Utterances that give an effect to institutional state of affairs. For example: declaring war, marrying, etc.

[10] Priest: I now pronounce you husband and wife.

[11] Referee: You're out!

However, in this research, the writer will only discuss commisives which is specified in promising act.

\section{CONTEXT}

Context is one of the most important parts in studying pragmatics. In this research, context is needed to understand the meaning of utterances that have been expressed by the characters, what is being promised, and the reason why the speaker utters it. Pragmatics involves the interpretation of what people mean in a particular context and how the context influences what is said. It requires a consideration of how the speakers organize what they want to say in accordance with who they are talking to, where, when, and 
under what circumstances (Yule, Pragmatics 3).

Another expert who has the same intention that context has an important role in pragmatics is Cutting. He suggests that there are three kinds of context (3):

Situational context: This context is what the participants know about what they can see around them where the interaction is taking place, including the gestures that can add meaning to the words.

Background knowledge context: This context is what the participants know about each other. This can be either cultural knowledge or interpersonal knowledge that brings the history of the participants.

Co-textual context or normally known as co-text: This context is what the participants know about what they have been saying. This involves grammatical cohesion such as reference, substitution, and ellipsis, and lexical cohesion such as repetitions, synonyms, superordinates, and general words.

Below is the excerpt that shows the importance of those contexts in understanding utterances.

[12] (Taken from Like Crazy) Jacob (hearer): "What are we going to do after we graduate?"

Anna (speaker): "We... We'll sort something out. Don't think about it now. I'll come back and I'll get a work visa."

Jacob (hearer): "I hate thinking about it."

Anna (speaker): "I'm not gonna leave. Promise."

Example [12] shows how Anna promises his boyfriend, Jacob that she will come back to America and get a work visa soon. The situational context is that when they have this conversation Anna strokes Jacob's cheeks while promising that she will be coming back and never leave Jacob. The cultural background of [12] is that both of them know that Anna will come back for a reason. Anna says that she will get a working visa. It means that she wants to stay with Jacob after she graduates. The last one, co-textual context is the word 'we' obviously refers to Anna and Jacob; it is an endophoric reference.

\section{PROMISES}

Promises belong to the category of commissives since the purpose of a commissives is to commit the speaker to perform an action. The speech act of promising can lead to misunderstandings. For instance, the hearer might believe what the speaker has promised although there is no word indicating promise explicitly. Otherwise, the hearer might doubt the intention to keep the promise when the speaker does not use the word 'promise'. Thus, all depends on the condition that involves a speaker and hearer.

There are certain conditions that must be met to identify a speech act. Searle draws four felicity conditions for promises (63). Below is one of the promises found in the movie Dear John. The example is followed by some explanations of felicity conditions.

[13] Savannah (hearer): "Oh, no, Randy, no!"

Randy (speaker): "I'm sorry. I'll get

it, I'll get it. I'm on it. I'm sorry. I'm sorry."

\section{a. Proportional Condition}

The utterance performed predicts some future act of the speaker. In a promise an act must be predicted by the speaker and it cannot be a past act. Example [13] shows how Randy promises Savannah to get her bag soon and it is clearly showing a future act of the speaker.

b. Preparatory Condition

A promise is to be uttered only if the hearer prefers the speaker to do an act and the speaker believes that the hearer will prefer him to do an act. Example [13] shows that Savannah wants Randy to perform an act and Randy as the speaker believes that Savannah prefers him to get the bag for her. 
c. Sincerity Condition

A promise is successfully made if the speaker intends to do an act. The distinction between sincere and insincere promises is that, in the case of sincere promises, the speaker intends to fulfill the promise; in the case of insincere promises, he does not intend to fulfill the promise. Example [13] shows that Randy has intention to get the bag for Savannah. He sincerely apologizes and promises Savannah to fulfill the promise.

\section{d. Essential Condition}

The essential feature of promise is the undertaking of an obligation to perform an act. In other words, the utterance obligates the speaker to do an act. Example [13] shows that the promise which has been expressed by Randy obligates him to do an act.

\section{EXPLICITNESS}

Below is the discussion of the types of utterances according to Austin (54-55). Following that, some explanations of explicitness will be presented. Austin divides utterances into two types. They are constatives and performatives. Constative sentences normally express statement of fact and can be proved as true or false. These are the examples of constative sentences:

[14] France is hexagonal (Austin 142).

[15] Naturally it is pretty rough (Austin 142).

Performative sentences indicate the performing of an action and they cannot be proved as true or false since they do not describe or report anything. The utterances show that the speaker is not only saying something, but also doing an action. Below are the examples of performative sentences:

[16] I do (Austin 5).

[17] I name this ship the Queen Elizabeth (Austin 5).

The name performatives is derived from the word 'perform'. It indicates that the meaning of the utterance is the performing of an action, not only the saying (Austin 6-7). This research only focuses on the performative utterances.

Now, some explanations of explicitness will be examined. Austin draws a difference within performative utterances between what he calls primary/implicit performatives and explicit performatives of promising act (69). In the following discussion, the term implicit performatives is used in categorizing the promises.

a. Implicit performatives: utterances containing a verb that indicates a promise. For example: "I shall be there," Based on Oxford Advanced Learner's Dictionary, the word 'shall' indicates the expression of future tense (Hornby 1394). As explained in the previous discussion, in a promise an act must be a future act.

b. Explicit performatives: utterances containing the verb 'promise'. For example: "I promise that I shall be there," Austin asserts that by saying "I promise that..." makes it unambiguously a promise. Besides, a performative formula as "I promise..." makes it understood that a promise has been made (70). Similarly, Searle states that the verb 'promise' shows the strongest sense for making promises in the English language (58).

\section{FELICITY CONDITIONS OF PROMISES}

The result of classification shows that the most frequent promising act appears in the movie Like Crazy with a total of 18 promises. The high frequency of promises might be caused by the story that tells how the characters try to keep their relationship going well. The main characters, Anna Gardner and Jacob Helm, have to struggle with their long distance relationship. During the separation, both Anna and Jacob begin another relationship. Anna starts dating her dormitory mate, Simon. Jacob also finds Samantha to fill his emptiness while his relationship with Anna is difficult. Anna and Jacob are separated by distance and 
both of them have found new partners in life, but they cannot hide their feeling that they miss each other. Living in the different countries, they feel hard to manage their relationship since they have to overcome problems like finding the right time to call. However, the condition becomes totally different when they get back living in the same city together, which happens several times. Anna and Jacob enjoy their togetherness and promise each other that everything will be fine. It can be concluded that they experience the ups and downs of a relationship. Therefore, more promises are expressed by the characters because they always try to reassure each other every time they get close.

Below is the table that shows the distribution of promises in the five movies.

Table 1: Number of Promises

\begin{tabular}{|r|l|r|r|r|r|}
\hline Nr. & Movies & MR & NO & \% & $\begin{array}{c}\text { Per 10 } \\
\text { Minutes }\end{array}$ \\
\hline 1. & Dear John & 108 & 17 & 23.29 & 1,57 \\
\hline 2. & $\begin{array}{l}\text { For Love of } \\
\text { the Game }\end{array}$ & 137 & 15 & 20.55 & 1,09 \\
\hline 3. & $\begin{array}{l}\text { Going the } \\
\text { Distance }\end{array}$ & 102 & 7 & 9.59 & 0,68 \\
\hline 4. & Like Crazy & 123 & 18 & 24.66 & 1,46 \\
\hline 5. & $\begin{array}{l}\text { The } \\
\text { Notebook }\end{array}$ & 90 & 16 & 21.91 & 1,77 \\
\hline \multicolumn{7}{r|}{ Total } & & $\mathbf{7 3}$ & $\mathbf{1 0 0 . 0 0}$ & \\
\hline
\end{tabular}

Notes :

MR = Movie Run-Time (in minutes)

NO $=$ Number of Occurrences

$\%=$ Percentage

The following section presents an example of promises found in the data. Following that, further explanations of the felicity conditions will be presented.

[18] [DJ - 00:26:08,680 --> 00:26:51,049]
Savannah feels very sad when she knows that the spring holiday is almost over. It means that she has to go back to school and John goes to the army. She expresses her worry in experiencing a long distance relationship. John then convinces her that everything will be fine. He promises Savannah that he will come back soon.

Savannah : "I leave tomorrow. I have to go back to school."

John : "So?"

Savannah : "And you."

John : "No, and me nothing. My commitment's up in 12 months. Then I'm back. For good."

Savannah : "A lot could happen in 12 months, John."

John : "You don't think I know that? I know that. And I'm not afraid at all. I promise you that it'll all be over sooner than you think. Then I'll be back for good."

Savannah :"You promise?"

John : "I promise."

\section{a. Proportional Condition}

In example [18], the act of being back is an act to be done in the future. The utterance "I'll be back for good," in the example [18] contains the word 'will', which indicates the expression of future act. It supports Searle's suggestion that in a promise, an act cannot be a past act and a speaker cannot promise something that has been done (57). To make a promise in the example [18], John does not utter "I would be back for good," or "I was going to be back for good,". Although those two utterances show the same intention in performing an act, they do not fulfill the proportional condition since the act promised is something that will not be performed in the future. The result shows that all of the promises found in the movies have fulfilled the proportional condition. It can be seen that those promises use the 
present tenses since the utterances do not report something, but perform something.

\section{b. Preparatory Condition}

To fulfill the preparatory condition, there are desires and beliefs between the interlocutors in making the promise to be realized. The dialogue in the example [18] indicates that Savannah prefers John to be back soon. Savannah shows her worry that a lot can happen in the twelve months of separation. Savannah tries to be supportive by allowing John goes to the army, but on the other hand she hopes that John will fulfill his promise by coming back once he finishes his service in the army. John, as the speaker also believes that the act of being back to Charleston is something Savannah wants.

\section{c. Sincerity Condition}

It can be seen in the example [18], John intends to fulfill the promise by going back to Charleston after he finishes the service in the army. John says that he knows a lot can happen in twelve months, but he is not afraid at all because he believes that everything will be fine and he will be back soon. John sincerely says to Savannah that he will be back soon even with a conviction that the twelve months of separation will be over sooner than Savannah thinks. To convince the hearer about his intention, the speaker usually gives some gestures in making promises. For instance, in the example [18], John hugs Savannah when he expresses his promise. He also speaks earnestly to prove that he is not joking. By adding some gestures, the speaker can express his sincerity and it also helps the hearer to evaluate whether the speaker really makes a sincere promise or not. The other way to show the intention of a promise is that the speaker may utter it explicitly. It can be seen in the example [18] where John makes an explicit promise to Savannah. In that situation, John tries to assure Savannah by making his promise explicitly since Savannah is too afraid of experiencing a long distance relationship. Hence, John may have some expectations that his promise is strong enough to show his intention.

\section{d. Essential Condition}

The essential condition is met when the act has been carried out. In other words, the promises uttered place the speakers under obligation to fulfill the promises. In the example [18], John carries out the act by coming back to Charleston after twelve months being separated from Savannah.

\section{TYPES OF PROMISES}

There will be two types of promises that will be discussed: implicit and explicit performatives. Out of the five movies, implicit performatives appears as the more dominant type of promises in the movie Like Crazy with 17 utterances. The high frequency of implicit performatives might be due to the details of the plot. Like Crazy tells how the main characters, Anna and Jacob overcome the obstacles of their long distance relationship. Implicit performatives is often used to perform a promise naturally. The promise sounds milder when it is uttered "I'll be there," rather than "I promise to be there".

The finding shows an interesting result since there are only 8 promises categorized as explicit performatives. It can be seen that 5 promises appear from the movie Dear John. The expression of explicit promises might be caused by the speakers' effort to show their intention. The speakers realize that the hearers will doubt the promises, so they try to convince the hearers by making the promises explicitly. When a promise is uttered explicitly such as "I promise I'll see you soon,", the hearer will have a belief that the utterance expressed is a promise.

The following table shows the types of promises in each movie. 
Table 2: Types of Promises in each Movie

\begin{tabular}{|c|c|c|c|c|c|}
\hline \multirow[t]{2}{*}{ Nr. } & \multirow[t]{2}{*}{ Movies } & \multicolumn{2}{|c|}{$\begin{array}{l}\text { Implicit } \\
\text { Performa- } \\
\text { tives }\end{array}$} & \multicolumn{2}{|c|}{$\begin{array}{l}\text { Explicit } \\
\text { Performa- } \\
\text { tives }\end{array}$} \\
\hline & & NO & $\%$ & NO & $\%$ \\
\hline 1. & Dear John & 12 & 18.46 & 5 & 62.5 \\
\hline 2. & $\begin{array}{l}\text { For Love } \\
\text { of the } \\
\text { Game }\end{array}$ & 15 & 23.08 & 0 & 0 \\
\hline 3. & $\begin{array}{l}\text { Going the } \\
\text { Distance }\end{array}$ & 6 & 9.23 & 1 & 12.5 \\
\hline 4. & $\begin{array}{l}\text { Like } \\
\text { Crazy }\end{array}$ & 17 & 26.15 & 1 & 12.5 \\
\hline 5. & $\begin{array}{l}\text { The } \\
\text { Notebook }\end{array}$ & 15 & 23.08 & 1 & 12.5 \\
\hline & Total & 65 & 100.00 & 8 & 100.00 \\
\hline
\end{tabular}

Notes :

$\mathrm{NO}=$ Number of Occurrences

$\%=$ Percentage

\section{Implicit Performatives}

The implicit performatives contains a verb, which indicates the speaker to do action without a commissive verb such as 'promise'. Below is an example showing the implicit performatives.

[19] [TN - 01:06:59,948 -->

$$
\text { 01:07:12,455] }
$$

Duke is reading a story for Allie in the hospital. Suddenly, the nurse comes to tell Duke that the doctor needs to see him. It annoys Allie because she still wants to hear the story and does not want Duke to leave. Therefore, Duke promises Allie that he will read more after seeing the doctor.

Nurse : "Doctor needs to see you."

Allie : "Me? Now?"

Nurse :"No, him."
Allie : "But he hasn't finished reading his story."

Duke : "I'll read some more when I'm through with the doctor. This shouldn't take too long."

Allie : "All right."

The example in [19] is considered as implicit performatives since it contains a verb, which indicates the intention of the speaker to do the act. In that example, the speaker does not express the promise explicitly. It is obvious that the speaker intends to fulfill the promises, so he expresses his willingness to the hearer by uttering "I will read...". Implicit performatives are often ambiguous in what purpose the utterance is expressed. It always depends on the situation that the speakers and hearers have.

\section{EXPLICIT PERFORMATIVES}

Unlike the implicit performatives, a promise is defined as explicit performatives when it contains the commissive verb such as 'promise'. Below is an example showing the explicit performatives.

$$
\begin{aligned}
& \text { [20] [LC - 00:24:44,941 --> } \\
& \text { 00:24:49,195] }
\end{aligned}
$$

The customs agent comes into Anna's waiting room. She cannot pass the passport customs because of the visa violation. Anna tells to Jacob on the phone that she has to go. Jacob tries to calm Anna down then promises that he will see Anna soon.

Anna : "I have to go now."

Jacob : "I'll see you soon, okay? I promise

\section{I'll see you soon."}

The example above belongs to explicit performatives since the speaker directly utter, "I promise" and it is clearly understood as a promise. It is similar with Searle's statement that "I promise" is the strongest illocutionary force indicating devices for commitment provided by the English language (58). Moreover, the 
performative verb 'promise' has successfully made the explicitness of the utterance's purpose. In the example above, the meaning of utterance is directly expressed. To assure the hearer, the speaker explicitly promises to perform an act. It, however, eliminates the hearer's assumption whether the expressed utterance is promise or not.

\section{CONCLUSION}

The results of this research show that there are 73 promises found in the five American drama movies entitled Dear John, For Love of the Game, Going the Distance, Like Crazy, and The Notebook. Based on the findings, it can be seen that the promises have fulfilled the felicity conditions. It was found that the most occurred promises were in the movie Like Crazy. Taking 108 minutes for the duration, Like Crazy presents 18 promises $(24,66 \%)$. The high number of promises might be due to the situation of the main characters of the story. As compared with the other four movies, Like Crazy, in fact, portraits the ups and downs of a long distance relationship and this kind of relationship is likely to create more promises since the main characters need to always assure their far away partners to maintain their relationship. Like Crazy is mostly showing the way Anna and Jacob relieve their worry in experiencing a long distance relationship. Hence, they promise each other to keep the relationship alive. It was also found that out of 18 promises, 9 promises $(50 \%)$ were expressed by the main characters, Anna and Jacob. The finding proves that Jacob and Anna, the participants of the long distance relationship, are the ones who express the more promises in the movie.

Context has proven to be a very important aspect in investigating this speech act of promising. Without it, people cannot see the meaning behind the performed utterances. With the help of the context, the analysis can be examined smoothly. Context also helps to enrich the knowledge behind an utterance. Hence, in this research, it helps the writer to notice the possibility of occurring the other types of speech acts.

The discussion proves that all of the promises that have been found in the movies fulfill Searle's felicity conditions. The realization of those felicity conditions is also shown in Al-Jawadi and AbdulMajeed's research. Since the previous researchers do not take the data from the subtitles of American drama movies in discussing felicity conditions, the result is evidently different from the present research.

In the present research, the categorization of promises shows that implicit performatives appear to be the more dominant type in the movies. From the data, $89,04 \%$ promises are categorized as implicit performatives, and only $10,96 \%$ promises are categorized as explicit performatives. Higher number of implicit performatives in the promises appears because the speakers might want to show their intention to do something in a casual way. The speakers might have assumed that the hearers will believe that the speakers will fulfill the promises in the future. Hence, the speakers do not always convince the hearers by uttering the promises explicitly. It supports Hickey who states that promises can also be expressed by non-commissive verbs. The verb that indicates a promise, such as 'will', involves a hearer and speaker of the intention of the speaker (76).

Although this research does not discuss the variable of age, familiarity, and social status, it can be concluded that those aspects do not affect the realization of promises. For example, in the movie Like Crazy, there is no difference whether Anna speaks to her mother or boyfriend. She always promises by uttering "I'll...". Anna does not consider that she should utter the promise explicitly when she speaks to someone older. Another example, in the movie Going the Distance, Erin also always promises someone implicitly. She performs 
implicit promises both when she talks to her boss and sister. As an internship employee, Erin might not think that by performing an explicit promise to her boss, she will give more politeness into her act.

\section{BIBLIOGRAPHY}

Austin, John L. How to Do Things with Words. Oxford: Oxford University Press, 1962. Print.

Cutting, Joan. Pragmatics and Discourse: A Resource Book for Students. London: Routledge, 2002. Print.

Grundy, Peter. Doing Pragmatics. Great Britain: Arnold, Hodder Headline Group, 2000. Print.

Hornby, A. S. Oxford Advanced Learner's Dictionary. Oxford: Oxford University Press, 2005. Print.

Leech, Geoffrey. Principles of Pragmatics. London: Longman Group Limited, 1983. Print.

Levinson, Stephen C. Pragmatics. Cambridge: Cambridge University Press, 1983. Print.

Mey, Jacob L. Pragmatics: An Introduction. United Kingdom: Blackwell Publishing, 2001. Second Edition. Print.

Searle, John R. Expression and Meaning. Studies in the Theory of Speech Acts. Cambridge: Cambridge University Press, 1979. Print.

Searle, John R. Speech Acts: An Essay in the Philosophy of Language. Cambridge: Cambridge University Press, 1969. Print.

Yule, George. Pragmatics. Oxford: Oxford University Press, 1996. Print.
Yule, George. The Study of Language. New York: Cambridge University Press, 2010. Print.

\section{ELECTRONIC REFERENCES}

Al-Jawadi, K, H., and Rufaidah Kamal Abdul Majeed. "Modification of Searle's Speech Act of Promising in its Application to Selected Religious and Political Texts." Journal of the College of Education for Women 18.1 (2007): 287-300. Iraqi Academic Scientific Journals. Web. 5 December 2012.

Goodman, Alison. "The Best Long Distance Relationships Ever Seen On-Screen." teen.com. Defy Media, 11 November. 2011. Web. 17 October 2013.

Hickey, R. "A Promise is A Promise: On Speech Acts of Commitment in English." Studia Anglica Posnaniensia 18 (1986): 69-80. Adam Mickiewicz University in Poznan. Web. 4 December 2012.

Livius, Besski. “Top 10 Long Distance Relationship Movies." long-distancelover.com. N.p., May. 2013. Web. 17 October 2013. 